\title{
Pengaruh Kompensasi Terhadap Kinerja Karyawan yang di Mediasi Kepuasan Kerja pada PT ISS Cikarang
}

\author{
Suwandi \\ Universitas Pelita Bangsa \\ suwandi@pelitabangsa.ac.id \\ Mahbub Mandahuri \\ Universitas Pelita Bangsa \\ mandahuri@gmail.com
}

\begin{abstract}
The purpose of this study is to determine whether there is an effect of compensation on job satisfaction mediated by job satisfaction. The object of research at PT ISS Cikarang. The research was conducted using quantitative methods with SEM Smart PLS software as an analysis tool. The number of samples obtained by using a random sampling technique using the Slovin formula totaled 97 respondents. Data collection was carried out using google form in filling out online surveys. The data analysis method used is the R-square test, Bootstrapping, Path Coefficient, and Specific indirect effects. The results of this study indicate that compensation has an effect on employee performance, compensation has a positive and significant effect on job satisfaction, job satisfaction affects employee performance, job satisfaction is able to provide a positive influence in mediating the relationship between compensation and employee performance in PT ISS Cikarang.
\end{abstract}

\section{Keywords Compensation, Job satisfaction, Employee performance}

\section{PENDAHULUAN}

Era global saat ini berbagai perusahaan menghadapi permasalahan di area kecil, menengah dan besar. Fenomena ini menggambarkan perkembangan area bisnis perusahaan. Diharapkan dengan berkembangnya sebuah organisaasi dapat dikembangkan sarana dan prasarana yang memadai serta pengelolaan sumber daya yang handal. Sumber daya manusia sangat penting karena manusia berperan aktif dan memimpin dalam setiap aktivitas organisasi. Orang-orang dalam organisasi bertindak sebagai penentu, peserta, dan perencana untuk mencapai tujuan perusahaan, menentukan kemajuan dan kemunduran perusahaan. Kemajuan persaingan saat ini menuntut orang yang dapat berpikir cerdas, inovatif serta maju untuk berkarya dan memiliki semangat tinggi dalam menghadapi era globalisasi (Rosmadi \& Tachyan, 2018). Manusia adalah sumber daya yang berbeda dari faktor produksi lainnya karena mereka memiliki perasaan, pikiran, keinginan, dan latar belakang yang berbeda. Manusia juga mempunyai kebutuhan yang tidak terbatas, artinya kebutuhan manusia selalu meningkat dari waktu ke waktu. Kebutuhan manusia diartikan sebagai segala sesuatu yang mereka miliki, ketahui, dan nikmati, sehingga orang termotivasi untuk melakukan aktivitas melalui pekerjaan. Sumber daya manusia perusahaan merupakan aspek penting yang menentukan efektivitas dan kesuksesan perusahaan. Jika tidak ada yang menjadi pengelola dan penyebar gagasan, maka perusahaan dengan sarana dan prasarana tidak ada artinya. Sebagai manusia, selain tujuan 
perusahaan yang harus dicapai karyawan juga memiliki tujuan pribadi, oleh karena itu tujuan perusahaan dan tujuan pribadi karyawan perlu diintegrasikan agar tidak terjadi tumpang tindih atau tumpang tindih. Kebutuhan setiap karyawan harus dipahami dan diperhatikan agar tujuan karyawan dapat terintegrasi dengan baik. Karyawan memiliki berbagai kebutuhan pribadi. Kebutuhan tersebut bersifat fisik dan non fisik dan harus dipenuhi untuk menjalani kehidupan yang normal.

Kinerja merupakan hasil kerja yang dilakukan oleh seseorang atau sekelompok orang dalam suatu organisasi, sesuai dengan kewenangan dan tanggung jawab Jawab masing-masing (Wartono, 2017). Hasil pekerjaan Sesuai dengan tujuan perusahaan Sangat bergantung pada pekerjaan karyawan. Pekerjaan karyawan dipengaruhi oleh beberapa faktor yaitu Faktor internal dan faktor eksternal. Faktor internal adalah terkait dengan karakteristik seseorang, termasuk sikap, ciri kepribadian, sifat tubuh, keinginan atau motivasi, usia, tipe gender, tingkat pendidikan, pengalaman kerja, latar belakang budaya dan variabel pribadi lainnya. Faktor eksternal yang mempengaruhi kinerja karyawan mencakup lingkungan, kepemimpinan, rekan kerja, jenis pelatihan dan pengawasan, serta sistem penggajian lingkungan sosial. Kinerja karyawan dalam organisasi merupakan bagian yang sangat penting, tidak terkecuali untuk PT ISS. Fenomena pada PT ISS yang terjadi saat ini adalah terkait menurunnya tingkat produktivitas kerja karyawan. Penurunan kinerja karyawan dari berbagai aspek atau faktorfaktor tertentu. Karyawan percaya bahwa kompensasi yang mereka terima tidak seperti yang mereka harapkan. Sebagian besar karyawan percaya bahwa kompensasi dalam bentuk gaji dan bonus tidak sesuai dengan harapan karyawan. Kompensasi yang diberikan perusahaan kepada karyawannya harus memenuhi harapan karyawan terbaik perusahaan.

Kompensasi merupakan pengganti yang diterima oleh karyawan sebagai kontribusi jasa mereka pada perusahaan. Mereka berkontribusi pada operasional perusahaan. Setiap karyawan dalam organisasi menginginkan kompensasi sesuai dengan ekspektasi mereka. Apabila harapan tersebut terpenuhi, maka karyawan tersebut akan senantiasa bersemangat dalam bekerja. Leonardo (2015) menyatakan bahwa departemen personalia merancang dan mengadministrasikan kompensasi karyawan. Apabila kompensasi yang diberikan sesuai, karyawan lebih terpuaskan dan termotivasi untuk mencapai sasaran organisasi. Organisasi berusaha memberikan pemenuhan kebutuhan karyawan melalui kompensasi. Jika karyawan mendapatkan gaji yang cukup besar maka kepuasan kerja mereka akan meningkat.Ini salah satu standar perusahaan yaitu menciptakan talenta dan menghasilkan kinerja terbaik dengan menjaga kepuasan kerja karyawan. Karyawan yang merasa puas dengan perusahaan akan menunjukkan loyalitasnya kepada perusahaan dan bekerja lebih keras, yang dapat membawa peluang bagi kesuksesan perusahaan. Keberhasilan perusahaan tidak hanya dapat dicapai melalui penerapan strategi bisnis, tetapi juga harus didukung oleh sumber daya manusia perusahaan. Oleh karena itu, sumber daya manusia juga dianggap sebagai kekuatan yang kompleks, dan kinerja karyawan berpengaruh langsung terhadap perusahaan.

Setiap orang yang bekerja ingin mendapatkan kepuasan dari tempat kerjanya. Kepuasan kerja akan mempengaruhi produktivitas yang diharapkan manajer. Oleh karena itu, organsiasi perlu memahami langkah-langkah yang harus dilakukan agar karyawan dapat bekerja dengan memuaskan, oleh karena itu perusahaan harus mampu menciptakan kondisi yang mendorong dan memungkinkan karyawan untuk mengembangkan dan meningkatkan kemampuan dan keterampilannya semaksimal mungkin. Salah satu langkah yang dapat dilakukan perusahaan untuk menciptakan kondisi tersebut adalah dengan memberikan kompensasi yang memuaskan. Salah satu cara untuk meningkatkan kinerja karyawan, dan kepuasan kerja adalah dengan memberikan kompensasi. Salah satu faktor yang perlu diperhatikan terkait dengan kinerja 
karyawan adalah apakah pekerja puas dengan pekerjaan mereka. Pekerja yang puas dengan pekerjaannya dapat dilihat dari adanya rasa semangat yang ditunjukkan pekerja dalam bekerja. Pekerja bersemangat dalam memenuhi standar kerja yang ditetapkan oleh perusahaan. Rosita (2016) menggambarkan apa yang membuat individu menginginkan dan menyenangi pekerjaannya dan mampu membuatnya merasa bahagia dalam pekerjaannya maupun memiliki keinginan untuk keluar dari pekerjaannya sebagai suatu bentuk dari rasa kepuasan kerja individu. Supriyanto (2013) mendefinisikan kepuasan kerja sebagai suatu bentuk emosi positif yang dihasilkan pekerja dari perasaan nyaman saat melakukan pekerjaannya.

Penggunaan kepuasan kerja sebagai variabel mediasi di dasarkan pada penelitian sebelumnya. Pekerja yang merasa puas dengan pekerjaannya cenderung meningkatkan kinerjanya sesuai dengan hasil yang diberikan perusahaan (Kurniawan, 2014). Changgriawan (2017) mengemukakan bahwa kepuasan kerja berpengaruh positif dan signifikan terhadap kinerja karyawan. Pekerja yang merasa puas dengan pekerjaannya akan meningkatkan kinerja dengan memberikan pelayanan terbaik dan bekerja semaksimal mungkin (Esthi \& Ekhsan, 2020; Nafiu \& Okpanachi, 2014; Parashakti \& Ekhsan, 2020). Karyawan dengan kepuasan kerja yang tinggi memiliki semangat kerja yang tinggi, sehingga prestasi kerjanya akan optimal dalam sebuah organisasi. Sebaliknya karyawan dengan kepuasan kerja yang rendah, menyebabkan prestasi kerjanya menjadi rendah. Karyawan menjadi tidak bersemangat dalam bekerja, dan ini akan sangat berdampak bagi perusahaan. Kepuasan kerja karyawan dinilai sangat penting terutama untuk menunjang kinerja perusahaan dalam persaingan di era globalisasi saat ini (Wijaya, 2014).

Kepuasan kerja karyawan merupakan fenomena yang harus diperhatikan oleh pimpinan organisasi. Kepuasan kerja karyawan sangat erat kaitannya dengan kinerja karyawan. Orang yang merasa puas akan memiliki motivasi yang tinggi, komitmen terhadap organisasi dan partisipasi kerja yang akan terus meningkatkan kinerjanya. Di sisi lain, kinerja karyawan yang lebih tinggi juga dapat mempengaruhi kepuasan kerja. Kepuasan kerja akan dikaitkan dengan partisipasi karyawan dalam organisasi. Jika kepuasan kerja tidak dapat dipertahankan, maka akan menghasilkan tingkat pergantian karyawan yang lebih tinggi di organisasi. Selain itu, produktivitas karyawan yang rendah, tingkat ketidakhadiran yang tinggi dan komitmen organisasi yang rendah juga dapat menyebabkan ketidakpuasan karyawan (Sinambela, 2012). Salah satu faktor yang mempengaruhi kepuasan kerja pekerja adalah melalui pemberian kompenasi. Seperti yang dijelaskan oleh Afrida (2014), perusahaan memberikan kompensasi kepada pekerja merupakan salah satu cara bagi perusahaan untuk meningkatkan prestasi kerja, motivasi, moral dan kepuasan kerja pekerja. Kompensasi pekerja biasanya digunakan untuk memenuhi kebutuhan terbesar mereka, termasuk makanan, minuman, pakaian, tempat tinggal, dll. Memenuhi kebutuhan pekerja melalui kompensasi dapat memberikan pekerja kepuasan kerja (Shah et al., 2011)

\section{LANDASAN TEORI \\ Kinerja karyawan}

Kinerja Memiliki kemampuan menghasilkan kinerja yang tinggi merupakan harapan setiap organisasi terhadap karyawannya. Menurut Mangkunegara (2016) kinerja merupakan hasil secara kualitas dan kuantitas yang dicapai oleh seseorang karyawan dalam melaksanakan tugasnya sesuai dengan tanggung jawab yang di berikan kepadanya. Kinerja merupakan penampilan individu maupun kerja kelompok personel. sedangkan kinerja pegawai (prestasi kerja) adalah hasil kerja secara kualitas dan kuantitas yang dapat dicapai oleh seseorang pegawai dalam melaksanakan tugasnya sesuai dengan tanggung jawab yang diberikan 
kepadanya. Siagian (2017) menjelaskan bahwa kinerja dapat diartikan sebagai hasil pekerjaan yang dicapai selama tahun waktu tertentu. Sedangkan Robbins (2013) menyatakan bahwa kinerja sebagai fungsi interaksi antara kemampuan, motivasi dan kesempatan, artinya kinerja merupakan fungsi dari kemampuan, motivasi dan kesempatan. Hasil kerja terdiri dari keberhasilan menyelesaikan pekerjaan, kepuasan dengan hasil kerja, dan adanya kesempatan. Tujuan dan sasaran pekerjaan meliputi memahami tujuan dan sasaran organisasi dan memahami sasaran pekerjaan. Penilaian prestasi dan umpan balik terdiri atas evaluasi prestasi, keadilan nilai dan penghargaan atasan. Dimensi kesempatan pengembangan meliputi kepuasan dengan peluang karir dan memiliki peluang pengembangan.

\section{Kompensasi}

Mangkunegara (2016) berpendapat kompensasi adalah sesuatu yang dipertimbangkan sebagai sesuatu yang sebanding. Efektivitas sistem kompensasi menjadi bagian terpenting dari Manajemen SDM karena membantu serta dapat mempertahankan bakat-bakat pekerjaan. Selain itu, kinerja strategis perusahaan dihasilkan oleh adanya sistem kompensasi. Menurut Subekhi (2012) kompensasi adalah setiap bentuk penghargaan yang diberikan karyawan sebagai balas jasa atas kontribusi yang mereka berikan kepada organisasi. Husnan (2011) menyatakan bahwa kompensasi adalah sejumlah balas jasa baik berupa uang, barang maupun kenikmatan yang biasa diterima oleh karyawan atas kinerja yang disumbangkan kepada perusahaan.

\section{Kepuasan Kerja}

Menurut Robbins (2017) menyatakan kepuasan kerja merupakan suatu perasaan positif tentang pekerjaan seseorang yang merupakan hasil dari sebuah evaluasi karakteristiknya. Kreitner \& Kinicki (2014), bahwa kepuasan kerja sebagai efektivitas atau respons emosional terhadap berbagai aspek pekerjaan. Terdapat dua belas kunci utama dalam kepuasan kerja, yaitu: input, hubungan manajer dan staf, disiplin kerja, lingkungan tempat kerja, istirahat dan makan yang cukup, diskriminasi, kepuasan kerja, penghargaan penampilan, klarifiksi kebijakan, mendapatkan kesempatan, pengambil keputusan dan peran manajer. Kepuasan kerja merupakan sikap seorang pegawai terhadap pekerjaannya, merasa senang atau tidak dengan cara memandang pekerjaan mereka sendiri.

\section{Pengembangan Hipotesis}

\section{Hubungan kompensasi dengan kinerja karyawan}

Pengaruh kompensasi terhadap kinerja menurut Wibowo (2017) berpendapat kompensasi ialah kontra prestasi terhadap penggunaan tenaga atau jasa yang telah diberikan oleh tenaga kerja.. Dengan demikian tentunya besarnya kompensasi mampu mempengaruhi perilaku pegawai yang tentunya akan berefek pada kinerja yang dihasilkan. Hal ini sesuai dengan penelitian yang dilakukan oleh Hameed (2014) menjelaskan bahwa kompensasi mampu mempengaruhi kinerja pegawai. Berdasarkan hasil dari penelitian terdahulu, maka dapat diajukan hipotesis sebagai berikut:

H1: kompensasi berpengaruh positif terhadap kinerja karyawan.

\section{Hubungan kompensasi dengan kepuasan kerja}

Pengaruh kompensasi terhadap kepuasan kerja Kompensasi memiliki arti penting karena kompensasi mencerminkan upaya organisasi dalam mempertahankan dan meningkatkan kesejahteraan karyawannya. Kreitner \& Kinicki (2014) bahwa kepuasan kerja sebagai 
efektivitas atau respons emosional terhadap berbagai aspek pekerjaan. Dengan diberikannya kompensasi yang proporsional sesuai dengan kinerjanya maka pegawai akan memiliki pandangan yang lebih (menyenangkan) terhadap organsasinya. Hal ini sejalan dengan pendapat Salisu et.al (2015) bahwa kompensasi berpengaruh positif terhadap kepuasan kerja, hal ini diperkuat dengan penelitian yang dilakukan oleh Humaeroh (2015) bahwa kompensasi finansial dan kompensasi non finansial berpengaruh secara simultan dan parsial terhadap kepuasan kerja. Berdasarkan hasil dari penelitian terdahulu, maka dapat diajukan hipotesis sebagai berikut:

H2: kompensasi berpengaruh positif terhadap kepuasan kerja.

\section{Hubungan kepuasan kerja dengan kinerja karyawan}

Pengaruh kepuasan kerja terhadap kinerja Kepuasan kerja merupakan respon afektif atau emosional terhadap berbagai aspek pekerjaan seseorang. Seseorang dengan tingkat kepuasan kerja tinggi memegang sikap positif terhadap pekerjaannya, sementara orang yang tidak puas dengan pekerjaannya memegang sikap negatif tentang pekerjaan. Kepuasan kerja merupakan hasil persepsi pegawai terhadap seberapa baik pekerjaan mereka. Sehingga semakin pegawai dikatakan puas maka kinerjanya akan semakin baik. Ahmad (2014) hasil menunjukkan adanya hubungan yang positif antara kepuasan kerja terhadap kinerja. Berdasarkan hasil dari penelitian terdahulu, maka dapat diajukan hipotesis sebagai berikut:

H3: Kepuasan kerja berpengaruh positif terhadap kinerja pegawai.

\section{Hubungan kompensasi dengan kinerja karyawan melalui kepuasan kerja}

Kompensasi lebih efektif berpengaruh secara langsung terhadap kinerja daripada dimediasi oleh kepuasan kerja. Dengan demikian adanya pemberian kompensasi yang sesuai dan tepat waktu serta proporsional berdasarkan kinerja yang dihasilkan akan memberikan dampak untuk semakin meningkatkan kinerja dengan asumsi adanya pemberian kompensasi yang sesuai, menjadi faktor utama untuk memacu kinerja yang dihasilkan. Hasil ini mengembangkan penelitian yang dilakukan oleh Syah (2013) menyatakan bahwa kompensasi memiliki hubungan yang positif dan signifikan dengan kepuasan kerja pekerja, karena ketika pekerja menerima kompensasi yang dirasa sebanding dengan pengorbanan yang telah diberikan akan menjadikan pekerja tersebut merasa puas. Berdasarkan hasil dari penelitian terdahulu, maka dapat diajukan hipotesis sebagai berikut:

H4: Kompensasi berpengaruh positif terhadap kinerja karyawan yang di mediasi kepuasan kerja.

\section{METODE PENELITIAN}

Metodologi yang dipilih adalah penelitian kuantitatif. Survei dikumpulkan melalui informasi kuantitatif yang dibutuhkan dan data dikumpulkan melalui kuesioner. Literatur review dilakukan untuk mengidentifikasi variabel kompensasi, kepuasan kerja dan kinerja karyawan. Kuesioner dikembangkan berdasarkan identifikasi variabel. Teknik pengambilan sample dalam penelitian ini menggunakan random sampling, sebanyak 97 responden di PT ISS Cikarang. Teknik pengambilan sampel melalui google form dalam mengisi survei online, selanjutnya menguatkan hasil penelitian dengan analisis deskriptif. Alat analisis yang digunakan dalam penelitian ini dengan software SEM Smart PLS.

\section{HASIL DAN PEMBAHASAN Pengujian Model Struktural}


Pengujian ini adalah pengujian terhadap suatu model struktural dengan melihat nilai dari $R$-square yang merupakan hasil dari uji goodness of fit model. Model kompensasi terhadap kinerja karyawan memberikan nilai $R$-square sebesar 0,580 yang dapat diintepretasikan bahwa variabel konstruk kinerja karyawan dapat dijelaskan oleh variabel konstruk kompensasi sebesar 58.0\% sedangkan $42.0 \%$ dijelaskan oleh variable lain diluar penelitian ini. Model pengaruh lainnya yaitu pada variable kepuasan kerja dengan nilai yang ditunjukan yaitu 0,503 sehingga dapat diintepretasikan bahwa $50.3 \%$ kontruk kepuasan kerja dengan variable terikat yaitu kompensasi dan kinerja karyawan. Sedangkan untuk $49.7 \%$ dijelaskan oleh variable lain yang tidak dimasukan pada penelitian ini. Dapat dilihat melalui tabel dibawah ini:

Tabel 2. R-square

\begin{tabular}{ll}
\hline & $R$-square \\
\hline Kinerja Karyawan & 0.580 \\
\hline Kepuasan Kerja & 0.503 \\
\hline
\end{tabular}

Sumber: Data Primer yang diolah, 2020

Setelah pengujian determinasi, maka dilakukan analisa jalur untuk mengetahui hubungan kausal antara variabel eksogen dengan endogen dengan melakukan bootstrapping pada smart pls 3.0 untuk mendapatkan prediksi dari hasil Analisa jalur pada model ini.

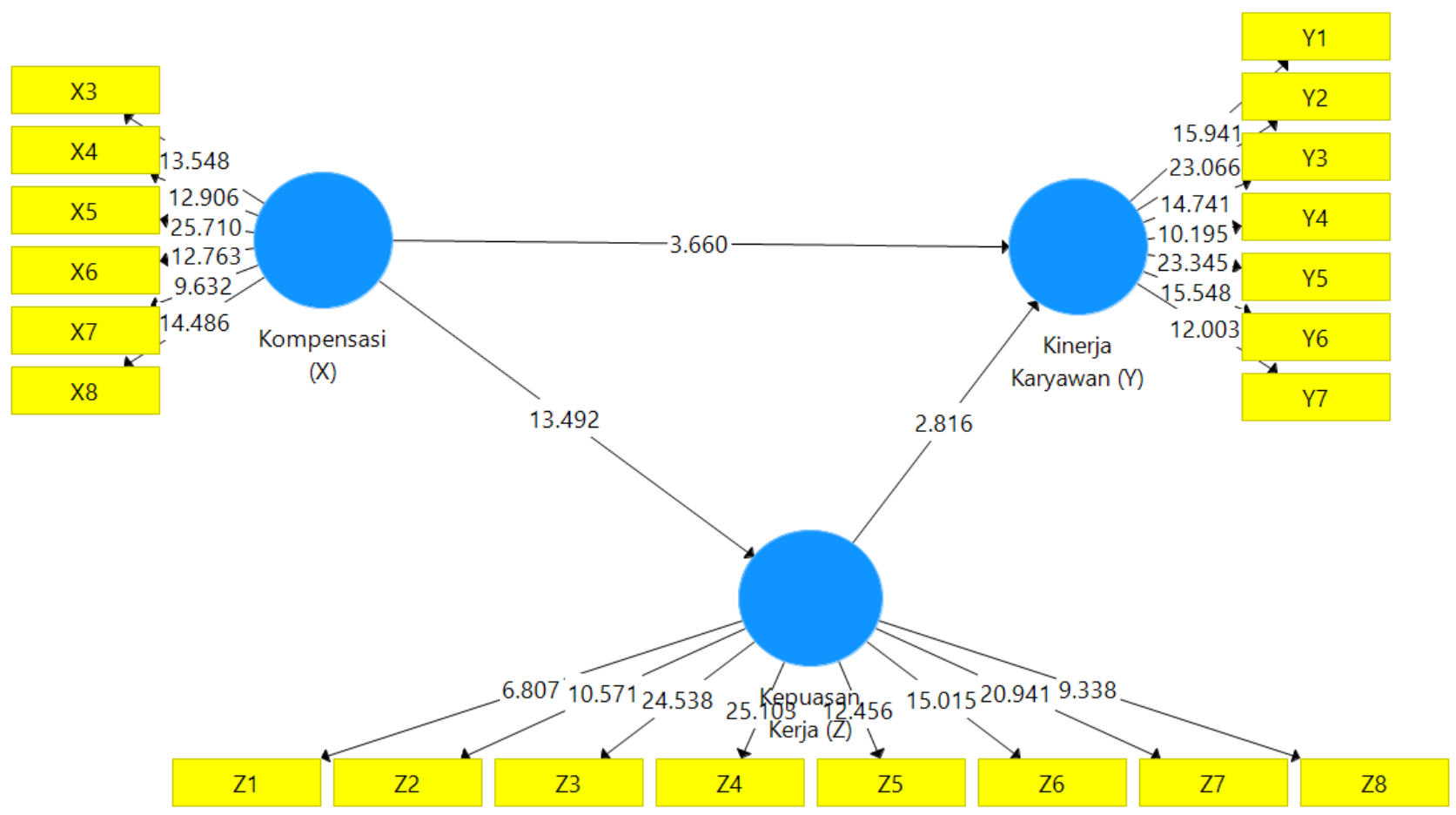

Sumber: Data Primer yang diolah, 2020

Gambar 1. bootstrapping 
Selanjutnya, dirinci pada tabel 2 path coefficient, yang menjelaskan nilai koefisien nilai $T$ value dan $\mathrm{P}$ value untuk menjadi acuan hubungan kasusal pada model ini.

Tabel 2. Path Coefficient

\begin{tabular}{cccccc}
\hline Variabel & $\begin{array}{c}\text { Original } \\
\text { Sample } \\
(\mathbf{O})\end{array}$ & $\begin{array}{c}\text { Sample } \\
\text { Mean } \\
(\mathbf{M})\end{array}$ & $\begin{array}{c}\text { Standard } \\
\text { Deviation } \\
(\mathbf{S T D E V})\end{array}$ & $\begin{array}{c}\text { T Statistics } \\
(\mid \mathbf{O} / \mathbf{S T D E V})\end{array}$ & $\begin{array}{c}\text { P } \\
\text { Values }\end{array}$ \\
\hline $\begin{array}{c}\text { Kompensasi }-> \\
\text { Kinerja Karyawan }\end{array}$ & 0.456 & 0.442 & 0.125 & 3.660 & 0.000 \\
\hline $\begin{array}{c}\text { Kompensasi -> } \\
\text { Kepuasan Kerja }\end{array}$ & 0.709 & 0.719 & 0.053 & 13.492 & 0.000 \\
\hline $\begin{array}{c}\text { Kepuasan Kerja-> Kinerja } \\
\text { Karyawan }\end{array}$ & 0.366 & 0.381 & 0.130 & 2.816 & 0.005 \\
\hline
\end{tabular}

Sumber: Data Primer yang diolah, 2020

Berdasarkan tabel 2. path coeffiecient yang menjelaskan pengaruh langsung, maka tabel 3 spesific indirect menjelaskan pengaruh tidak langsung.

Tabel 3. Specific Indirect Effects

\begin{tabular}{cccccc}
\hline Variabel & $\begin{array}{c}\text { Original } \\
\text { Sample } \\
(\mathbf{O})\end{array}$ & $\begin{array}{c}\text { Sample } \\
\text { Mean (M) }\end{array}$ & $\begin{array}{c}\text { Standard } \\
\text { Deviation } \\
(\text { STDEV) }\end{array}$ & $\begin{array}{c}\text { T Statistics } \\
(\mid \mathbf{O} / \text { STDEV|) }\end{array}$ & $\begin{array}{c}\text { P } \\
\text { Values }\end{array}$ \\
\hline $\begin{array}{c}\text { Kompensasi -> Kepuasan } \\
\text { Kerja -> Kinerja Karyawan }\end{array}$ & 0.260 & 0.277 & 0.104 & 2.500 & 0.013 \\
& & & & & \\
\hline
\end{tabular}

\section{Sumber: Data Primer yang diolah, 2020}

Variabel kompensasi memiliki pengaruh yang positif dan signifikan terhadap variabel kinerja karyawan. Artinya semakin besar kompensasi yang diterima maka akan semakin baik kinerja yang dihasilkan. Dengan demikian besarnya kompensasi mampu mempengaruhi perilaku pegawai yang tentunya akan berdampak pada kinerja yang dihasilkan. Kompensasi yang semakin besar memberikan jaminan, sehingga secara total pegawai dapat memberikan tenaganya bagi organisasi. Dengan totalitas tersebut tentunya dapat menghasilkan kinerja yang maksimal. Hasil penelitian ini sejalan dengan penelitian yang dilakukan oleh Hameed (2014) yang menunjukkan hasil bahwa kompensasi memiliki pengaruh positif terhadap kinerja.

Variabel kompensasi memiliki pengaruh yang positif dan signifikan terhadap variabel kepuasan kerja. Artinya semakin besar kompensasi yang diterima, semakin tinggi tingkat kepuasan kerja pegawai. Dengan diberikannya kompensasi yang proporsional sesuai dengan kinerjanya maka pegawai akan memiliki pandangan yang lebih menyenangkan terhadap organisasinya sehingga akan memiliki persepsi yang positif dengan pekerjaan yang dilakukan. Hasil penelitian ini sejalan dengan pendapat Salisu et.al (2015) bahwa kompensasi berpengaruh positif terhadap kepuasan kerja.

Variabel kepuasan kerja memiliki pengaruh yang positif dan signifikan terhadap variabel kinerja karyawan. Artinya semakin tinggi kepuasan kerja maka semakin tinggi pula kinerja. Kepuasan kerja yang tinggi berarti bahwa pegawai puas dengan adanya jaminan dalam bekerja, diperlakukan dengan baik oleh rekan-rekan kerja, memiliki kesempatan yang cukup untuk melakukan pekerjaan, puas dalam hal gaji, tunjangan, promosi jabatan, perasaan senang bekerja dengan pemimpin, sehingga pegawai akan merasa cocok bekerja di tempat ia bekerja 
dan berusaha bekerja sebaik-baiknya agar bisa bertahan di organisasi tersebut. Hasil penelitian ini didukung oleh penelitian yang dilakukan oleh Ahmad (2014) yang menunjukkan hasil bahwa ada pengaruh yang signifikan antara kepuasan kerja terhadap kinerja.

Variabel kompensasi memiliki pengaruh yang positif dan signifikan terhadap variabel kepuasan kerja yang di mediasi kepuasan kerja. Dengan demikian adanya pemberian kompensasi yang sesuai dan tepat waktu serta proporsional berdasarkan kinerja yang dihasilkan akan memberikan dampak untuk semakin meningkatkan kinerja dengan asumsi adanya pemberian kompensasi yang sesuai, menjadi faktor utama untuk memacu kinerja yang dihasilkan serta ada kepuasan dalam bekerja . Hasil penelitian ini sejalan dengan penelitian yang dilakukan oleh Sukatrini (2014) yang menjelaskan bahwa kepuasan kerja tidak memediasi pengaruh kompensasi terhadap kinerja

\section{KESIMPULAN}

Kompensasi berpengaruh terhadap kinerja karyawan. Kompensasi berpengaruh terhadap kepuasan kerja. Kepuasan kerja berpengaruh terhadap kinerja karyawan. Kompensasi berpengaruh terhadap kinerja karyawan yang di mediasi kepuasan kerja. Hal ini dapat diartikan bahwa semakin adil, layak dan wajar pemberian kompensasi yang diberian perusahaan maka karyawan akan senang, dihargai, bekerja keras dan memiliki semangat juang yang tinggi serta semakin tinggi kepuasan kerja karyawan. Kepuasan kerja berperan penting sebagai mediator pengaruh kompensasi terhadap kinerja karyawan. Melalui tingginya kepuasan kerja maka karyawan memiliki semangat mengembangkan karir. Hal ini berdampak pada kualitas kerja yang baik, tugas sesuai waktu yang telah ditentukan dan bisa melaksanakan tugas dengan optimal.

\section{DAFTAR PUSTAKA}

Afrida, Z. (2014). Pengaruh Kompensasi Finansial dan Non Finansial terhadap Motivasi Kerja dan Kinerja Karyawan (Studi pada Karyawan Departemen Produksi PT. Ekamas Fortuna Malang). Jurnal Administrasi Bisnis, 12(1).

Ahmad, M., Nawaz, M., Iqbal, M., \& Javed, S. (2014). Analysing the Impact of Climate Change on Rice Productivity in Pakistan.

Changgriawan, G. S. (2017). Pengaruh kepuasan kerja dan motivasi kerja terhadap kinerja karyawan di One Way Production. Agora, 5(2).

Dhyan Parashakti, R., Ekhsan, M., \& Dian Nusantara, U. (n.d.). The Effect of Discipline and Motivation on Employee Performance in PT Samsung Elektronik Indonesia. http://ejournal.stie-kusumanegara.ac.id

Esthi, R. B., \& Ekhsan, M. (2020). The Effect of Millennial Intrinsic Value toward Employee Outcomes with Employee Benefit as Mediating Variable for Strengthening Indonesia's Startup Business. Solid State Technology, 63(2s).

Hameed, A., Ramzan, M., \& Zubair, H. M. K. (2014). Impact of compensation on employee performance (empirical evidence from banking sector of Pakistan). International Journal of Business and Social Science, 5(2). 
Humaeroh, H. (2015). Pengaruh Kompensasi terhadap Kepuasan Kerja Karyawan dan Dampaknya terhadap Motivasi Kerja (Studi pada Karyawan PT Krakatau Steel (Persero) Tbk.). Brawijaya University.

Husnan, S. (2011). Heidjrachman. Manajemen Personalia.

Kreitner, R., \& Kinicki, A. (2014). Organizational behavioral. Boston: McGraw-Hill.

Kurniawan, K. A. (2014). Pengaruh Tingkat Work-Life Balance Terhadap Tingkat Kepuasan kerja Pada Perawat Rumah Sakit. E-Journal.

Leonardo, E. (2015). Pengaruh pemberian kompensasi terhadap kinerja karyawan pada PT. Kopanitia. Agora, 3(2), 28-31.

Mangkunegara, A. A. A. P. (2016). Manajemen sumber daya manusia perusahaan. PT. Remaja Rosdakarya.

Nafiu, A. T., \& Okpanachi, E. V. (2014). An Empirical Study of the Dialectical Relationship between Job Satisfaction and Job Performance of Restaurant Employees in Dekina Local Government of Kogi State, Nigeria. International Journal of Academic Research in Business and Social Sciences, 4(5), 596.

Parashakti, R. D., \& Ekhsan, M. (2020). The Effect of Discipline and Motivation on Employee Performance in PT Samsung Elektronik Indonesia. Journal of Research in Business, Economics, and Education, 2(3), 653-660.

Robbins, S. P., \& Judge, T. A. (2017). Organizational Behavior. 17, global ed. Harlow: Pearson Education Limited.

Robbins, S. P., Judge, T., \& Langton, N. (2013). Fundamentals of organizational behaviour. W. Ross MacDonald School Resource Services Library.

Rosita, T., \& Yuniati, T. (2016). Pengaruh kepuasan kerja terhadap kinerja karyawan dengan komitmen organisasional sebagai variabel intervening. Jurnal Ilmu Dan Riset Manajemen (JIRM), 5(1).

Rosmadi, M. L. N., \& Tachyan, Z. (2018). Pengaruh Pelatihan, Disiplin, dan Pengembangan Karir Terhadap Kinerja Karyawan. IKRA-ITH HUMANIORA: Jurnal Sosial Dan Humaniora, 2(2), 18-26.

Salisu, J. B., Chinyio, E., \& Suresh, S. (2015). The impact of compensation on the job satisfaction of public sector construction workers of jigawa state of Nigeria. The Business \& Management Review, 6(4), 282.

Shah, S. S. H., Jaffari, A. R., Aziz, J., Ejaz, W., Ul-Haq, I., \& Raza, S. N. (2011). Workload and performance of employees. Interdisciplinary Journal of Contemporary Research in Business, 3(5), 256-267. 
Siagian, S. P. (2017). Manajemen sumber daya manusia. Bumi Aksara.

Sinambela, L. P. (2012). Kinerja Pegawai Teori Pengukuran dan Implikasi. Yogyakarta: Graha Ilmu.

Subekhi, A., \& Jauhar, M. (2012). Pengantar manajemen sumber daya manusia (MSDM). Jakarta: Prestasi Pustaka.

Sukatrini, D. (2014). Pengaruh Budaya Organisasi dan Lingkungan Kerja Terhadap Kinerja Karyawan Dengan Kepuasan Kerja Sebagai Variabel Mediasi Pada Konveksi 1 Pt. Dan Liris Sukoharjo. UNS (Sebelas Maret University).

Supriyanto, A. S. (2013). Role of procedural justice, organizational commitment and job satisfaction on job performance: The mediating effects of organizational citizenship behavior. International Journal of Business and Management, 8(15), 57-67.

Syah, H. (2013). Pengaruh kompensasi finansial terhadap kepuasan kerja dan motivasi kerja karyawan pada PT. Graha Raja Empat. Jurnal Ilmu Manajemen (JIM), 1(2).

Wartono, T. (2017). Pengaruh stres kerja terhadap kinerja karyawan (studi pada karyawan majalah Mother and Baby). KREATIF: Jurnal Ilmiah Prodi Manajemen Universitas Pamulang, 4(2).

Wibowo, H. A. (2017). PENGARUH KOMPENSASI, LINGKUNGAN KERJA NON FISIK DAN MOTIVASI KERJA TERHADAP KEPUASAN KERJA KARYAWAN (Sentra Industri Keripik Tempe Sanan). University of Muhammadiyah Malang.

Wijaya, F. J. (2014). Pengaruh Komitmen Organisasional dan Kepuasan Kerja Karyawan terhadap Organizational Citizenship Behavior (Ocb) di PT Xyz Surabaya. Agora, 2(2), 1574-1579. 